www.volsu.ru

DOI: https://doi.org/10.15688/jvolsu11.2017.4.8

UDC 911.9

LBC 26.17

\title{
ECO-ECONOMIC ASSESSMENT OF THE SYR DARYA BASIN WITH THE USAGE OF GEOINFORMATION TECHNOLOGIES
}

\author{
Stanislav S. Shinkarenko \\ FSC of agroecology RAS; Volgograd State University, \\ Volgograd, Russian Federation \\ Denis A. Solodovnikov \\ Volgograd State University, Volgograd, Russian Federation \\ Gulnara N. Nyussupova \\ Al-Farabi Kazakh National University, Almaty, Kazakhstan \\ Andrey A. Denisov \\ Volgograd State University, Volgograd, Russian Federation
}

\begin{abstract}
The article presents the possible ways of using geoinformation technologies for environmental management in the Syr Darya basin (one of the most important Central Asian river). The ecological and economic role of this river increased when the North Aral Sea was split from the Big Aral one by the Kokaral dam. It is necessary to regulate water consumption by all the countries of the basin - Kyrgyzstan, Uzbekistan, Tajikistan and Kazakhstan republics. Based on the statistics data of CAWater-IS (the "Regional Information System on the Use of - Water and Land Resources in the Aral Sea Basin") some thematic layers for the geoinformation system of the Syr Darya basin have been developed. Attributive information contains data about the structure of land use in different administrative units of the republics of the basin - the share and areas of irrigated land, the amounts of water abstraction for various needs, landscape differentiation into types and subtypes of landscapes, the area of saline lands and the degree of salinity, areas under different crops and etc. The main consumer of water in the basin above the Shar Darya reservoir is Uzbekistan (up to $80 \%$ ), the largest areas of saline lands are located in Kazakhstan, and the main cultivated crops are cotton and cereals.
\end{abstract}

Key words: Syr Darya, the Aral Sea, Central Asia, Kazakhstan, Kyrgyzstan, Uzbekistan, Tajikistan, GIS.

\section{ЭКОЛОГО-ХОЗЯЙСТВЕННАЯ ОЦЕНКА БАССЕЙНА СЫРДАРЬИ} С ПРИМЕНЕНИЕМ ГЕОИНФОРМАЦИОННЫХ ТЕХНОЛОГИЙ

\section{Станислав Сергеевич Шинкаренко}

Федеральный научный центр агроэкологии, комплексных мелиораций и защитного лесоразведения Российской академии наук; Волгоградский государственный университет, г. Волгоград, Российская Федерация

\section{Денис Анатольевич Солодовников}

Волгоградский государственный университет, г. Волгоград, Российская Федерация

\section{Гульнара Нурмухамедовна Нюсупова}

Казахский национальный университет им. ал-Фараби, г. Алматы, Республика Казахстан 


\title{
Андрей Александрович Денисов
}

Волгоградский государственный университет, г. Волгоград, Российская Федерация

\begin{abstract}
Аннотация. В статье представлены возможности применения геоинформационных технологий для регулирования природопользования в бассейне важнейшей центральноазиатской реки - Сырдарьи. После отделения Северного Аральского моря Кокаральской плотиной от Большого Арала экологическая и экономическая роль этой реки возросла. Необходимо регулирование водопотребления всеми странами бассейна - республиками Кыргызстан, Узбекистан, Таджикистан и Казахстан. На основе статистических данных «Региональной информационной системы по использованию водно-земельных ресурсов в бассейне Аральского моря» (CAWater-IS) разработаны некоторые тематические слои для геоинформационной системы бассейна Сырдарьи. Атрибутивная информация содержит сведения о структуре землепользования в разных административных единицах республик бассейна - доле и площадях орошаемых земель, величинах водозабора на различные нужды, ландшафтной дифференциации на типы и подтипы ландшафтов, площадах засоленных земель и степени засоления, площадях под различными сельскохозяйственными культурами и т. д. Главным потребителем воды в бассейне выше Шардарьинского водохранилища является Узбекистан (до 80 \%), наибольшие площади засоленных земель расположены в Казахстане, а основными возделываемыми культурами являются хлопок и зерновые.
\end{abstract}

Ключевые слова: Сырдарья, Аральское море, Средняя Азия, Казахстан, Кыргызстан, Узбекистан, Таджикистан, ГИС.

До середины XX века Аральское море было одним из крупнейших морей-озер на планете, ежегодно в Арал поступало до $60 \mathrm{kм}^{3}$ вод Сырдарьи и Амударьи [2]. В результате интенсивного освоения пустынь и полупустынь увеличился забор воды на орошение, составив $2 / 3$ естественного стока крупнейших среднеазиатских рек. Разбор воды практически вдвое превысил сток обеих рек в Аральское море. Итогом стала потеря Аральским морем рыбохозяйственного значения, деградация ландшафтов долин Амударьи и Сырдарьи, ухудшение климатических условий и др. В конце концов, Арал разделился на две части - Северное Аральское море (Малый Арал) и южную часть (Большой Арал). Из-за растущей разницы в уровнях между частями водоток в перемычке между ними постепенно врезался все глубже и вода уходила из северной части в южную. Для предотвращения перетока воды к 2005 году была построена Кокаральская плотина с проектным уровнем в 42 метра. Лишняя вода сбрасывается гидроузлом в южную часть Арала [5]. Появился новый водоем, питаемый водами самой длинной реки Центральной Азии - Сырдарьи. Причем уровень моря достаточно устойчив, а минерализация снижается: в среднем 9,5 г/л против 20 г/л в 1994 г. [7]. Таким образом, создание Северного Аральского моря способствовало восстановлению целостности природнохозяйственного комплекса казахстанской ча- сти Аральского бассейна. Теперь от рациональности использования водных ресурсов Сырдарьи зависит судьба нового водоема и прилегающих ландшафтов. Анализ проб воды из реки показал, что концентрация хлоридов и фосфатов не превышает 0,113 г/л и 0,5 г/л соответственно.

Речная система Сырдарьи относится к бассейну Аральского моря, образуется при слиянии Нарына и Карадарьи в Ферганской долине и охватывает следующие страны: Республика Кыргызстан (Баткенская, Жалалабадская, Нарынская и Ошская области), Республика Узбекистан (Андижанская, Джизанская, Наманганская, Сырдарьинская, Ташкентская и Ферганская области), Согдийская область Республики Таджикистан и Республика Казахстан (Кызылординская и Южно-Казахстанская области) [19]. Среднемноголетний сток Сырдарьи составляет 40,8 км³/год. На реке расположены пять водохранилищ: Токтогульское, Андижанское, Кайраккумское, Чарвакское и Шардаринское. В процентном соотношении водозабор из реки составляет: Казахстан 41,5 \%, Кыргызстан - 0,82 \%, Таджикастан 7,44 \%, Узбекистан - 50,24 \% [11]. По этой причине рациональное использование водных ресурсов Сырдарьи невозможно без международного сотрудничества государств $[22,23,26]$. Единая геоинформационная система бассейна, отражающая водопотребление, земельные ресурсы, эффективность сельского хозяйства и 
др. может стать одним из инструментов такого сотрудничества $[15,17]$.

Материалы и методы исследований. В работе использованы методы геоинформационного картографирования на основе статистической информации, данных дистанционного зондирования и картографических материалов свободного доступа. В качестве базовой основы использованы слои административных границ и гидросети проекта Open Street Map. Статистические данные взяты в «Региональной информационной системепо использованию водно-земельных ресурсов в бассейне Аральского моря» (CAWater-IS) [14]. Ландшафтная дифференциация приводится согласно ландшафтной карте СССР [18]. Геоинформационная обработка произведена в программe QGIS 2.14. Для гидрохимических исследований воды из реки Сырдарья и пойменных грунтовых вод была использована переносная биохимическая лаборатория «Крисмас+».

Результаты и обсуждение. На рисунке 1 показана ландшафтная карта бассейна Сырдарьи.

На территории государств, к которым относится бассейн Сырдарьи, преобладают следующие подтипы ландшафтов: северопустынные (12,2 \%), пустынно-степные низкогорья $(11,5)$, южнопустынные $(10,8$ \%), степные и пу- стынно-степные среднегорья (10\%), пустынные высокогорья (9,7 \%), луговые и лугово-степные высокогорья (6,9 \%). Остальные подтипы (лугово-степные и степные высокогорья, степные низкогорья, лугово-лесные среднегорья, ксерофитно-кустарниково-редколесные среднегорья и высокогорья, степные низкогорья и ледники) суммарно занимают 9,4\%.

Согласно ботанико-географическому районированию территории принадлежат к Северотуранской, Джунгарской, Южнотуранской, Джунгаро-Северотяньшаньской, Горносреднеазиатской, Копетдаг-Хорасанской и Североиндукушской провинциям Ирано - Таранской подобласти и Горноцентрально-азиатской провинции Центрально-Азиатской подобласти Сахаро-Гобийской пустынной области [4].

В Таджикистане около 4580 тыс. га земель отведены для сельскохозяйственного производства, в том числе 3300 тыс. га пастбищ, 750 тыс. га пахотных земель, свыше 100 тыс. га многолетних насаждений. Земли гослесфонда занимают 1700 тыс. га Почвы Таджикистана подвержены деградационным процессам под воздействием антропогенной деятельности. Водная эрозия и дефляция характерны для сероземных почв, коричневые почвы разрушаются в результате интенсивного выпаса и распашки. Все большую роль при-

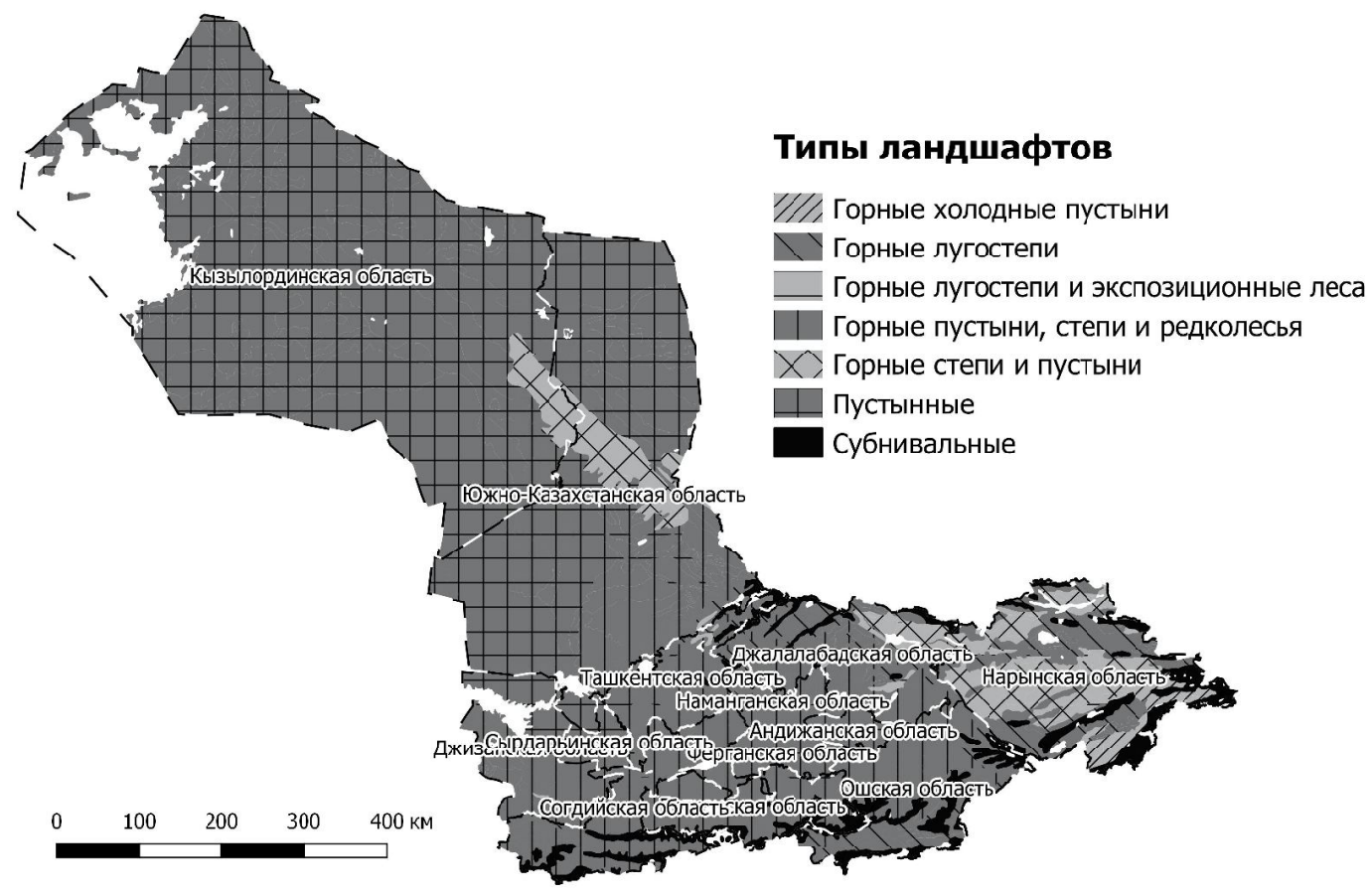

Рис. 1. Ландшафтная карта бассейна Сырдарьи 


\section{ГЕОГРАФИЯ И ГЕОИНФОРМАТИКА}

обретает роль пастбищных нагрузок в нарушении высокогорных лугово-степных почв.

В Казахстане площадь сельскохозяйственных угодий составляет примерно 222,5 млн га, из которых 185,2 млн га пастбищных земель, 21,9 млн га пашни, 5 млн га сенокосов и до 10,3 млн га залежных земель. Площадь орошаемой пашни достигает 1400 тыс. га из общей площади орошаемых земель в 2300 тыс. га. Более 1500 тыс. га земель республики подвержены дефляции, водной эрозии подвержены пахотные земли, например, в Южно-Казахстанской области 317,7 тыс. га эродированных земель [20, 21].

Из-за дефицита воды на орошение в начале 1990-х годов в Узбекистане прекратилось интенсивное освоение новых земель и удалось уйти от монокультуры хлопка. В настоящее время в республике стараются под- держивать положительный баланс гумуса в почве за счет органических удобрений и внедрения севооборотов [12]. В целом по бассейну, наибольшие площади заняты сельскохозяйственными культурами в Узбекистане 2287 тыс. га, в Казахстане с 691 тыс. га, в Таджикистане (277 тыс. га) и Кыргызстане (239 тыс. га). В таблице 1 представлено распределение пахотных земель под различными сельскохозяйственными культурами в бассейне Сырдарьи.

Хлопок занимает лидирующую позицию среди всех культур - 26,2 \% площади, при этом в отдельных странах бассейна доля колеблется от $13 \%$ в Кыргызской республике (31 тыс. га) до $31 \%$ в Узбекистане (715 тыс. га). Почти такую же площадь в бассейне занимают зерновые $(25,6 \%)$, при этом в относительном выражении площадь зерновых максимальна в Тад-

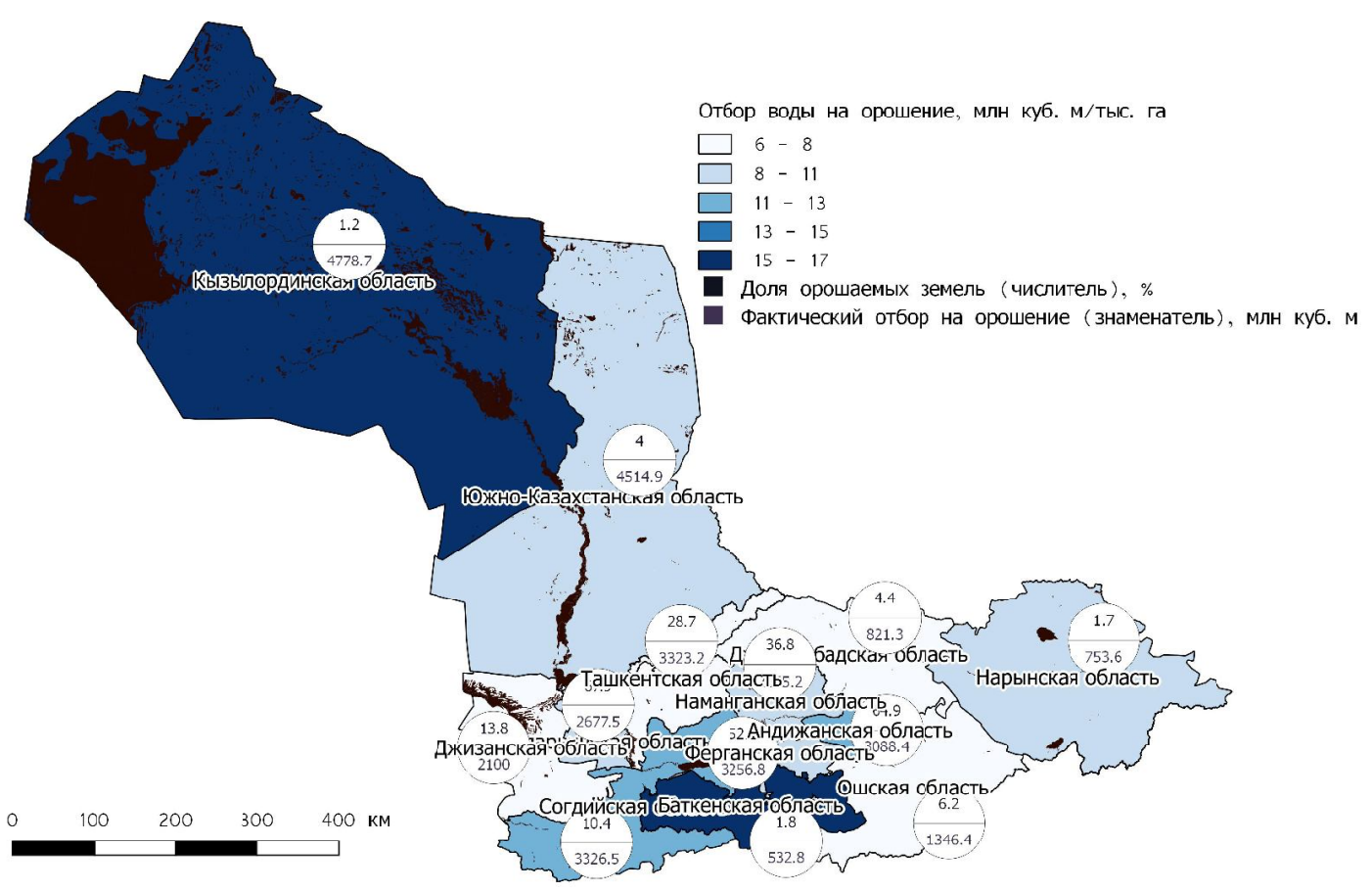

Рис. 2. Отбор воды на орошение субъектами стран в бассейне Сырдарьи

Таблица 1

Распределение площадей под посевами сельскохозяйственных культур в странах бассейна Сырдарьи

\begin{tabular}{|l|c|c|c|c|c|c|c|c|c|c|}
\hline \multirow{2}{*}{ Государство } & \multicolumn{9}{|c|}{ Распределение площади с/х культр } \\
\cline { 2 - 12 } & $\begin{array}{c}\text { Хлоп- } \\
\text { чатник }\end{array}$ & $\begin{array}{c}\text { Кормо- } \\
\text { вые }\end{array}$ & Сады & $\begin{array}{c}\text { Зерно- } \\
\text { вые }\end{array}$ & $\begin{array}{c}\text { Приу- } \\
\text { садебные }\end{array}$ & $\begin{array}{c}\text { Куку-- } \\
\text { руза }\end{array}$ & $\begin{array}{c}\text { Бахче- } \\
\text { вые }\end{array}$ & $\begin{array}{c}\text { Карто- } \\
\text { фель }\end{array}$ & $\begin{array}{c}\text { Рис } \\
\text { радни- }\end{array}$ \\
\hline Казахстан & $15,9 \%$ & $24,5 \%$ & $4,4 \%$ & $26,7 \%$ & $4,0 \%$ & $4,2 \%$ & $1,7 \%$ & $1,1 \%$ & $13,1 \%$ & $1,3 \%$ \\
\hline Кыргызстан & $13,0 \%$ & $25,2 \%$ & $10,9 \%$ & $7,3 \%$ & $22,2 \%$ & $10,7 \%$ & $0,9 \%$ & $1,7 \%$ & $1,3 \%$ & $1,5 \%$ \\
\hline Таджикистан & $22,1 \%$ & $15,8 \%$ & $5,6 \%$ & $35,6 \%$ & $4,5 \%$ & $2,0 \%$ & $1,9 \%$ & $3,6 \%$ & $1,0 \%$ & $3,8 \%$ \\
\hline Узбекистан & $31,3 \%$ & $10,3 \%$ & $13,5 \%$ & $26,0 \%$ & $8,7 \%$ & $1,5 \%$ & $0,5 \%$ & $1,0 \%$ & $1,2 \%$ & $2,1 \%$ \\
\hline
\end{tabular}


жикистане (35,6 \%, 98,4 тыс. га), но в абсолютном лидирует Узбекистан - 595,5 тыс. га.

Относительно велика доля кормовых культур (от 43 тыс. га в Таджикистане до 235 тыс. га в Узбекистане) и садов (от 15,5 тыс. га до 309 тыс. га).

Наибольшая доля засоленных земель из всех государств бассейна принадлежит Узбекистану - 60,4 \% всех засоленных земель (табл. 2). Но при этом преобладают почвы со слабым засолением: на узбекистанскую часть бассейна Сырдарьи приходится 71 \% всех слабозасоленных земель, 20,7 \% сильно засоленных и 56 \% незасоленных. Наибольшая доля засоленных земель в Сырдарьинской, Ферганской и Джизанской областях.

Сильно- и сверх-засоленные почвы, главным образом, сосредоточены в казахстанской части бассейна $-73,4 \%$, также на Казахстан приходятся 47,9 \% умеренно засоленных земель всего бассейна. Это связано с преобладанием пустынных типов ландшафтов. Если рассматривать дифференциацию земель Казахстана по засолению, то к незасоленным относятся $38 \%$. На Кыргызстан и Таджикистан приходится незначительная доля засоленных земель бассейна $-2 \%$ и 2,6 \% соответственно, при этом в республиках преобладают незасоленные почвы.

Суммарный объем забора из Сырдарьи выше Шардаринского водохранилища в последнее десятилетие колеблется от 8 до 11 км³ $^{3}$, при этом отмечен тренд на рост водозабора [6]. Лидером по водопотреблению является Узбекистан - от $70 \%$ до $80 \%$ всего забора воды на этом участке бассейна (табл. 3). Причем в последние годы наблюдается увеличение забора воды из реки, но связано это в первую очередь с увеличением водности, значительная доля которого приходится на зимнее время $[8,13,24]$.

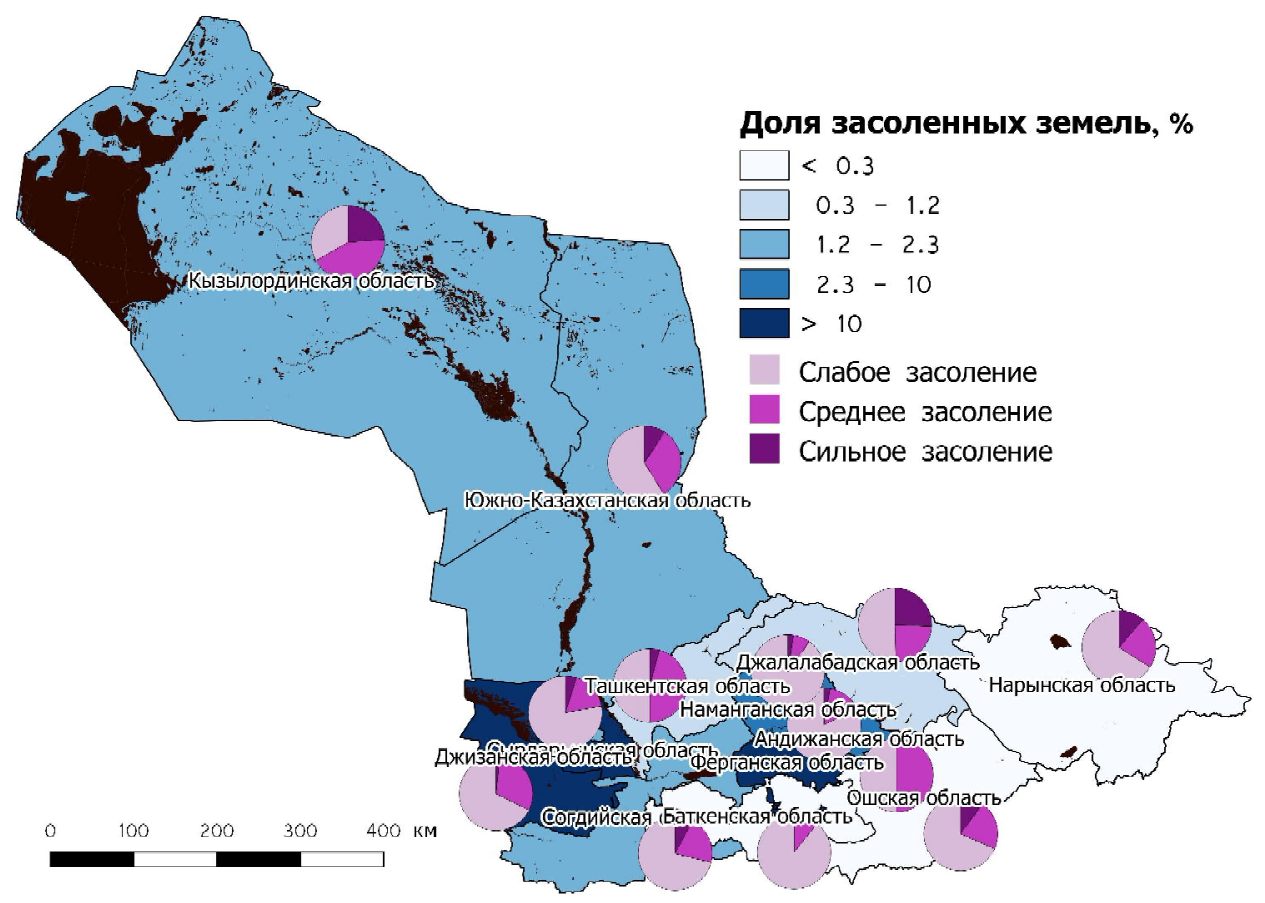

Рис. 3. Засоленные земли в бассейне Сырдарьи

\section{Площади земель различной степени засоления в бассейне Сырдарьи}

\begin{tabular}{|l|c|c|c|c|c|}
\hline \multirow{2}{*}{ Государство } & \multicolumn{4}{|c|}{ Площади земель разной степени засоления, тыс. га } \\
\cline { 2 - 6 } & $\begin{array}{c}\text { Нет } \\
\text { засоления }\end{array}$ & Слабое & Умеренное & $\begin{array}{c}\text { Сильное/ } \\
\text { сверхсильное }\end{array}$ & $\begin{array}{c}\text { Всего } \\
\text { засоленных }\end{array}$ \\
\hline Казахстан & 289,1 & 208,0 & 173,1 & 88,2 & 469,3 \\
\hline Кыргызстан & 448,1 & 16,2 & 5,8 & 4,4 & 26,4 \\
\hline Таджикистан & 257,3 & 24,4 & 7,2 & 2,7 & 34,3 \\
\hline Узбекистан & 1267,0 & 608,5 & 175,6 & 24,9 & 809,0 \\
\hline
\end{tabular}


Показатели водопотребления из бассейна Сырдарьи

\begin{tabular}{|l|c|c|c|c|c|c|c|c|}
\hline \multirow{2}{*}{\multicolumn{1}{|c|}{ Показатель }} & \multicolumn{7}{|c|}{ Объем воды, км } \\
\cline { 1 - 10 } & 2010 & 2011 & 2012 & 2013 & 2014 & 2015 & 2016 & 2017 \\
\hline $\begin{array}{l}\text { Подача воды в } \\
\text { Арал и Приаралье }\end{array}$ & 4,26 & 1,57 & 2,85 & 1,47 & 2,00 & 1,23 & 1,2 & 4,22 \\
\hline \multicolumn{1}{|c|}{ Водопотребитель } & \multicolumn{7}{|c|}{ Водозабор выше Шардаринского вдхр., км ${ }^{3}$} \\
\hline Казахстан & 0,68 & 0,61 & н/д & 0,54 & 0,46 & 0,57 & 0,44 & 0,74 \\
\hline Кыргызстан & 0,17 & 0,18 & 0,13 & 0,23 & 0,17 & 0,17 & 0,19 & 0,19 \\
\hline Узбекистан & 7,34 & 8,43 & 3,89 & 7,94 & 6,55 & 6,91 & 6,64 & 8,67 \\
\hline Таджикистан & 1,28 & 1,45 & 0,07 & 1,45 & 1,72 & 1,5 & 1,55 & 1,59 \\
\hline
\end{tabular}

В условиях изменений климата, тенденции которых направлены на потепление и рост увлажнения холодного полугодия и аридизацию за счет вегетационного периода, возрастает роль орошения в поддержании сельскохозяйственного производства $[3,9]$. Увеличение зимних сбросов каскадом гидроузлов в интересах энергетической отрасли только увеличит нехватку водных ресурсов с весны до осени $[1,10]$.

Заключение. Сведение статистической информации по различным показателям (географические, социальные, экономические и др.) в геоинформационную систему позволяет наглядно отображать пространственную структуру водопотребления странами бассейна Сырдарьи и их субъектами. Процессы регулирования гидрологического режима важнейшей водной артерии Средней Азии должны учитывать интересы всех водопользователей: производство электроэнергии в верховьях, орошение в среднем и нижнем течении, а также обеспечение населения водой на всем протяжении реки. Только межгосударственное взаимодействие способствует рациональному неистощительному использованию водных ресурсов Сырдарьи. Единая геоинформационная система может стать инструментом контроля соблюдения межправительственных соглашений, регулирующих водопотребление и отраслевые интересы экономик.

\section{СПИСОК ЛИТЕРАТУРЫ}

1. Абдужалилов, Ф. З. Моделирование вопросов согласования интересов между ирригацией и гидроэнергетикой: трансграничный аспект / Ф. 3. Абдужалилов // Вестник Таджикского государственного университета права, бизнеса и по- литики. Серия общественных наук. - 2012. - № 1.С. $125-131$.

2. Айзель, Г. В. Исследование динамики уровня воды Аральского моря по данным дистанционного зондирования и климатического реанализа / Г. В. Айзель, А. С. Ижицкий // Водные ресурсы: изучение и управление (лимнологическая школапрактика). - Т. 2. - 2016. - С. 189-194.

3. Берсенева, И. А. Климаты аридной зоны / И. А. Барсенева // Биологические ресурсы и природные условия Монголии. Труды совместной Российско-Монгольской комплексной биологической экспедиции. T. XLVI. - M. : Наука, 2006. - 287 с.

4. Ботаническая география Казахстана и Средней Азии (в пределах пустынной области) / ред. Е. И. Рачковская, Е. А. Волкова, В. Н. Хрализова. СПб., 2003. -424 c.

5. Духовный, В. А. Аральское море и Приаралье. Обобщение работ НИЦ МКВК по мониторингу состояния и анализу ситуации / В. А. Духовный. - Ташкент : Научно-информационный центр МКВК, 2015. $-107 \mathrm{c}$.

6. Каюмов, А. Внерегиональные державы в центральноазиатском узле водно-энергетических проблем / А. Каюмов, Е. Омельченко // Центральная Азия и Кавказ. - 2014. - Т. 17. - Вып. 1.- С. 51-62.

7. Кипшакбаев, Н. Восстановление экологической системы в дельте Сырдарии и северной части Аральского моря / Н. Кипшакбаев, Ю. Шуттер, В. А. Духовный. - Алматы : ЭВЕРО, 2010. - 220 с.

8. Коновалов, В. Г. Расчет и прогноз составляющих стока в бассейнах рек Центральной Азии / В. Г. Коновалов // Известия РАН. Серия географическая. -2015 . - № 3. - С. 72-84.

9. Кузьмина, Ж. В. Климатические изменения в Приаралье и Средней Азии / Ж. В. Кузьмина, С. Е. Трешкин // Аридные экосистемы. - 2016. T. 22. - № 4 (69). - C. 5-20.

10. Кузьмина, Ж. В. Формирование растительности на солончаках обсохшего дна Аральского моря в изменяющихся климатических условиях / Ж. В. Кузьмина, С. Е. Трешкин // Доклады Российской академии сельскохозяйственных наук. -2009 . T. 35. - № 1. - C. 32-35. 
11. Курбанбаев, Е. Аральское море и водохозяйственная политика в республиках Центральной Азии / Е. Курбанбаев, О. Артыков, С. Курбанбаев. Нукус : Каракалпакстан, 2010. - 144 с.

12. Никанорова, А. Д. Оценка водного дефицита на ирригационных землях ферганской долины в условиях изменения климата / А. Д. Никанорова, Е. В. Миланова, Н. М. Дронин // Аридные экосистемы. - 2016. - том 22. - № 4 (69). - С. 43-51.

13. Попова, В. П. Определение потерь стока по длине реки Сырдарья в пределах республики Казахстан/ В. П. Попова, А. Н. Мусенова // Гидрометеорология и экология. - 2010. - № 1. - С. 100-108.

14. Региональная информационная система по использованию водно-земельных ресурсов в бассейне Аральского моря (CAWater-IS) [электронный pecypc]. режим доступа: http://www.cawater-info. net/data_ca/ (Проверен 10 сентября 2017 г.).

15. Рогожина, Н.Г. Конфликтный потенциал водных ресурсов Центральной Азии / Н.Г. Рогожина // Россия и новые государства Евразии. - 2014. №1.- С. 44-54.

16. Самбаев, Н.С. Современное гидроэкологическое состояние нижнего течения реки Сырдарья и использование ее ресурсов стока / Н.С. Самбаев // Астраханский вестник экологического образования. - 2017. - №2 (40). - С. 50-55.

17. Чодураев, Т.М. Проблема экологической оптимизации использования водных ресурсов в бассейне реки Сырдарья / Т.М. Чодураев, Т.Ч. Тажиева // Наука и новые технологии. - 2012. - № 4. C. $131-133$.

18. Швиденко, А. Леса и лесное хозяйство России/ А. Швиденко, Д. Щепащенко, Я. МакКаллум Международный институт прикладного системного анализа и Российская Академия наук. - Лаксенбург, Австрия, 2007. [Электронный ресурс] режим доступа: http://www.iiasa.ac.at/ Research/FOR/forest_cdrom/ index.html (Проверен 10 сентября 2017 г.).

19. Glazyrin, G. E. The reaction of glaciers in Western Tien Shan to climate change / G. E. Glazyrin // Zeitschrift fuer Gletscherkunde und Glazialgeologie. 1996. - № 32. - pp. 33-39.

20. Gleason, G. Inter-State Cooperation in Central Asia from the CIS to the Shanghai Forum / G. Gleason // Europe - Asia Studies. - 2001. - Vol. 53. - № 7. pp. 1077-1095.

21. Heaven, S. Water Resources Management in the Aral Basin: a River Basin Management Model for the Syr Darya / S. Heaven, G. B. Koloskov, A. C. Lock // Irrigation and Drainage. - 2002. - Vol. 51 - № 2. pp. 109-118.

22. Murakaev, R. R. Water, Climate, Food, and Environment in the Syr Darya Basin, Contribution to the project ADAPT, Adaptation strategies to changing environments / R. R. Murakaev / Project funded by the Dutch Ministry of Foreign Affairs. 2003. [electronic resource], URL: http://www.weap21.org/downloads/ AdaptSyrDarya.pdf.

23. Murray-Rust, H. Water productivity in the Syr-Darya River Basin / H. Murray-Rust, I. Abdullaev, M. Hassan. - Colombo, Sri Lanka : IWMI, 2003. - 75 p.

24. Raskin, P. Simulation of Water Supply and Demand in the Aral Sea Region / P. Raskin, E. Hansen, Z. Zhu // Water International. - 1992. - № 17. - pp. 55-67.

25. Taltakov, I. The Syr Darya river - new ecological disaster in Central Asia / I. Taltakov // Acta Sci. Pol. Formatio Circumiectus. - 2015. - № 14 (4). p. 135-140.

\section{REFERENCES}

1. Abduzhalilov F. Z. Modelirovanie voprosov soglasovaniya interesov mezhdu irrigatsiei i gidroenergetikoi: transgranichnyi aspekt [Modeling issues of harmonizing interests between irrigation and hydropower: the transboundary aspect]. Vestnik Tadzhikskogo gosudarstvennogo universiteta prava, biznesa i politiki. Seriya obshchestvennykh nauk, 2012, no 1, pp. 125-131.

2. Aizel' G. V., Izhitskii A.S. Issledovanie dinamiki urovnya vody Aral'skogo morya po dannym distantsionnogo zondirovaniya i klimaticheskogo reanaliza [Research of water level dynamics in the Aral Sea according to remote sensing and climate reanalysis data]. Vodnye resursy: izuchenie i upravlenie (limnologicheskaya shkola-praktika), vol. 2, 2016, pp. 189-194.

3. Berseneva, I.A. Klimaty aridnoi zony [Climates of the arid zone]. Biologicheskie resursy $i$ prirodnye usloviya Mongolii. Trudy sovmestnoi Rossiisko-Mongol'skoi kompleksnoi biologicheskoi ekspeditsii. vol. 46. Moscow, Nauka, 2006, 287 p.

4. Rachkovskaya E.I., Volkova E.A., Khralizova.Botanicheskaya V.N. eds Botanicheskaya geografiya Kazakhstana i Srednei Azii (v predelakh pustynnoi oblasti) [Botanical geography of Kazakhstan and Central Asia (within the desert area)]. Sankt-Petersburg, 2003, 424 p.

5. Dukhovnyi V.A. Aral'skoe more i Priaral'e. Obobshchenie rabot NITs MKVK po monitoringu sostoyaniya $\mathrm{i}$ analizu situatsii (The Aral Sea and the Aral region. Generalization of SIC ICWC work on condition monitoring and situation analysis). Tashkent: Nauchno-informatsionnyi tsentr MKVK, 2015, 107 p.

6. Kayumov A., Omel'chenko E. Vneregional'nye derzhavy $v$ tsentral'noaziatskom uzle vodnoenergeticheskikh problem [Extra-regional powers in the Central Asian knot of water and energy problems]. Tsentral'naya Aziya i Kavkaz. 2014, vol. 17, no. 1, pp. 51-62. 
7. Kipshakbaev N., Shutter Yu., Dukhovnyi V.A., Vosstanovlenie ekologicheskoi sistemy v del'te Syrdarii i severnoi chasti Aral'skogo morya [Restoration of the ecological system in the delta of the Syr Darya and the northern part of the Aral Sea], Almaty: "EVERO”, 2010, 220 p.

8. Konovalov V.G. Raschet i prognoz sostavlyayushchikh stoka $\mathrm{v}$ basseinakh rek Tsentral'noi Azii [Estimation and Forecast of Components of Runoff in the River Basins of Central Asia]. Izvestiya RAN. Seriya geograficheskaya. 2015, no 3, pp. $72-84$.

9. Kuz'mina Zh.V., Treshkin S.E. Klimaticheskie izmeneniya v Priaral'e i Srednei Azii [Climate change in the Aral sea region and Central Asia]. Aridnye ekosistemyArid ecosystems. 2016, vol. 22, no 4 (69), pp. 5-20.

10. Kuz'mina Zh.V., Treshkin S.E. Formirovanie rastitel'nosti na solonchakakh obsokhshego dna Aral'skogo morya v izmenyayushchikhsya klimaticheskikh usloviyakh [Formation of vegetation on solonchaks of the dried bottom of the Aral Sea in changing climatic conditions]. Doklady Rossiiskoi akademii sel'skokhozyaistvennykh nauk. 2009, vol. 35, no 1, pp. 32-35.

11. Kurbanbaev E., Artykov O., Kurbanbae S. Aral'skoe more i vodokhozyaistvennaya politika $\mathrm{v}$ respublikakh Tsentral'noi Azii [The Aral Sea and water policy in the Central Asian republics]. Nukus, "Karakalpakstan", 2010, 144 p.

12. Nikanorova A.D., Milanova E.V., Dronin N.M. Otsenka vodnogo defitsita na irrigatsionnykh zemlyakh ferganskoi doliny v usloviyakh izmeneniya klimata [Estimation of water deficit under climate change and irrigation conditions in the Fergana valley of Central Asia]. Aridnye ekosistemy - Arid ecosystems. 2016, vol. 22. no 4 (69), pp. 43-51.

13. Popova V.P., Musenova A.N., Opredelenie poter' stoka po dline reki Syrdar'ya v predelakh respubliki Kazakhstan [Determination of flow losses along the length of the Syr Darya River within the Republic of Kazakhstan]. Gidrometeorologiya i ekologiya. 2010, no 1, pp. 100-108.

14. Regional'naya informatsionnaya sistema po ispol'zovaniyu vodno-zemel'nykh resursov v basseine Aral'skogo morya (CAWater-IS) [Regional Information System on the Use of Water and Land Resources in the Aral Sea Basin]. Available at: http:.www.cawaterinfo.netdata_ca (accessed 10 September 2017).,

15. Rogozhina N.G. Konfliktnyi potentsial vodnykh resursov Tsentral'noi Azii [Conflicting potential of water resources in Central Asia]. Rossiya i novye gosudarstva Evrazii. 2014, no 1, pp. 44-54.

16. Sambaev N.S. Sovremennoe gidroekologicheskoe sostoyanie nizhnego techeniya reki Syrdar'ya i ispol'zovanie ee resursov stoka [Current hydroecological state of the lower watercourse of Syr dariya and use of her resources of the drain]. Astrakhanskii vestnik ekologicheskogo obrazovaniya. 2017, no 2 (40), pp. 50-55.

17. Choduraev T.M., Tazhieva T.Ch. Problema ekologicheskoi optimizatsii ispol'zovaniya vodnykh resursov v basseine reki Syrdar'ya [The problem of ecological optimization of water resources use in the Syrdarya river basin]. Nauka i novye tekhnologii. 2012, no 4, pp. 131-133.

18. Shvidenko A., Shchepashchenko D., MakKallumi Ya. Lesa i lesnoe khozyaistvo Rossii [Forests and forestry in Russia]. Mezhdunarodnyi institut prikladnogo sistemnogo analiza i Rossiiskaya Akademiya nauk. Laksenburg, Avstriya. 2007. Available at: http:.www.iiasa.ac.at ResearchFOR forest cdromindex.html (accessed 10 September 2017).

19. Glazyrin G.E. The reaction of glaciers in Western Tien Shan to climate change. Zeitschrift fuer Gletscherkunde und Glazialgeologie. 1996, no 32, pp. 33-39.

20. Gleason G. Inter-State Cooperation in Central Asia from the CIS to the Shanghai Forum. Europe Asia Studies. 2001, vol. 53, no 7, pp. 1077-1095.

21. Heaven S., Koloskov G.B., Lock A.C. Water Resources Management in the Aral Basin: a River Basin Management Model for the Syr Darya. Irrigation and Drainage. 2002, vol. 51, no 2, pp. 109-118.

22. Murakaev R.R Water, Climate, Food, and Environment in the Syr Darya Basin, Contribution to the project ADAPT, Adaptation strategies to changing environments. Project funded by the Dutch Ministry of Foreign Affairs. 2003, Available at: http:.www. weap21.orgdownloadsAdaptSyrDarya.pdf (accessed 10 September 2017).

23. Murray-Rust H, Abdullaev I., Hassan M. Water productivity in the Syr-Darya River Basin. Colombo, Sri Lanka, IWMI. 2003, 75 p.

24. Raskin P., Hansen E., Zhu Z. Simulation of Water Supply and Demand in the Aral Sea Region. Water International. 1992, no 17, pp. 55-67.

25. Taltakov I. The Syr Darya river - new ecological disaster in Central Asia. Acta Sci. Pol. Formatio Circumiectus. 2015, no 14 (4), pp. 135-140. 
Эколого-хозяйственная оценка бассейна Сырдарьи с применением геоинформационных технологий

\section{Information about the Authors}

Stanislav S. Shinkarenko, Candidate of Agricultural Sciences, Researcher in FSC of agroecology RAS, Prospekt Universitetskij, 97, 400062 Volgograd, Russian Federation; Associate Professor of Department of Geography and Cartography, Volgograd State University, Prospekt Universitetskij, 100, 400062 Volgograd, Russian Federation, vnialmi@bk.ru.

Denis A. Solodovnikov, Candidate of Geographical Sciences, Head of Department of Geography and Cartography, Volgograd State University, Prospekt Universitetskij, 100, 400062 Volgograd, Russian Federation, densolodovnikov@gmail.com,solodovnikov@volsu.ru.

Gulnara N. Nyussupova, Doctor of geography, Professor, Head of Department of Geography, Land management and Cadastre, Al-Farabi Kazakh National University, Prospekt al-Farabi, 71, 050040 Almaty, Kazakhstan, Gulnara.Nyusupova@kaznu.kz.

Andrey A. Denisov, Candidate of Biological Sciences, Associate Professor of Department of Ecology and Environmental management, Volgograd State University, Prospekt Universitetskij, 100, 400062 Volgograd, Russian Federation, econecol@volsu.ru.

\section{Информация об авторах}

Станислав Сергеевич Шинкаренко, кандидат сельскохозяйственных наук, научный сотрудник, Федеральный научный центр агроэкологии, комплексных мелиораций и защитного лесоразведения Российской академии наук, просп. Университетский, 97, 400062 г. Волгоград, Российская Федерация; доцент кафедры географии и картографии, Волгоградский государственный университет, просп. Университетский, 100, 400062 г. Волгоград, Российская Федерация, vnialmi@bk.ru.

Денис Анатольевич Солодовников, кандидат географических наук, заведующий кафедрой географии и картографии, Волгоградскиий государственный университет, просп. Университетский, 100, 400062 г. Волгоград, Российская Федерация, densolodovnikov@gmail.com, solodovnikov@volsu.ru.

Гульнара Нурмухамедовна Нюсупова, доктор географических наук, профессор, заведующая кафедрой географии, землеустройства и кадастра, Казахский национальный университет им. ал-Фараби, просп. аль-Фараби, 71, 050040 г. Алматы, Республика Казахстан, Gulnara.Nyusupova@kaznu.kz.

Андрей Александрович Денисов, кандидат биологических наук, доцент кафедры экологии и природопользования, Волгоградский государственный университет, просп. Университетский, 100, 400062 г. Волгоград, Российская Федерация, econecol@volsu.ru. 